\title{
PENGEMBANGAN LEMBAR KERJA SISWA (LKS) BERBASIS POE (PREDICT, OBSERVE, EXPLAIN) PADA MATERI SUHU DAN KALOR SMP/MTs KELAS VII
}

\author{
Serlis Mariyana ${ }^{1)}$, Maison ${ }^{2)}$, dan Ahmad Syarkowi ${ }^{3)}$ \\ ${ }^{1)}$ Mahasiswa Program Studi Pendidikan Fisika FKIP Universitas Jambi \\ ${ }^{2) 3}$ Dosen Pogram Studi Pendidikan Fisika FKIP Universitas Jambi \\ Email: junserlis82@gmail.com
}

\section{Info Artikel}

\section{Alamat Korespondensi:}

Email: junserlis82@gmail.com

\begin{abstract}
Abstrak:
Tujuan dari penelitian ini adalah untuk menghasilkan dan mengetahui persepsi siswa terhadap LKS Berbasis POE (Predict-Observe-Explain) pada Materi Suhu dan Kalor. Jenis penelitian ini adalah penelitian dan pengembangan (research and development) dengan model pengembangan R\&D Sugiyono. Penelitian ini melalui tahap identifikasi masalah, pengumpulan informasi, desain produk, validasi desain, perbaikan desain, uji coba produk, revisi produk, uji coba pemakaian, revisi produk tahap akhir dan produksi masal. Subjek penelitian yaitu siswa/i SMPN 1 Kota Jambi kelas VII. Instrumen yang digunakan adalah angket validasi ahli materi dan media serta angket persepsi siswa. Teknik analisis data yaitu berupa saran dari validator yang dilakukan secara deskriptif kualitatif. Sedangkan skor angket validasi dan angket persepsi siswa dilakukan secara kuantitatif. LKS ini disusun berdasarkan langkah-langkah dari model pembelajaran POE yang terdiri dari orientation and motivation (orientasi dan motivasi), introduction the experiment (petunjuk praktikum), prediction (prediksi), observation (observasi) and explanation (penjelasan). LKS ini telah divalidasi oleh validator dan dinyatakan valid dengan skor ahli materi sebesar 4.16 dan skor validasi oleh ahli media sebesar 3.8 yang termasuk dalam kategori baik. Selanjutnya, skor hasil persepsi siswa terhadap LKS berbasis POE yaitu 3.37 dan dikategorikan sangat setuju. Keunggulan dari LKS ini yaitu dilengkapi gambar dan petunjuk praktikum yang sederhana serta terdapat uraian tahapan kegiatan yang disajikan secara jelas dan terperinci sesuai dengan tahapan POE. Adapun kekurangan dari LKS ini yaitu belum memiliki contoh soal dan pengayaan setelah melakukan percobaan kegiatan.
\end{abstract}

Kata kunci: LKS, POE, suhu dan kalor 


\section{Pendahuluan}

Pada kegiatan belajar mengajar yang dilaksanakan di sekolah guru berperan aktif sebagai pembentuk pengetahuan yang artinya guru berperan sebagai fasilitator. Kegiatan belajar mengajar tersebut membutuhkan sumber belajar guna menunjang keterlaksanaannya. Sumber belajar yang digunakan siswa dapat berupa buku paket maupun buku Lembar Kerja Siswa (LKS) yang biasanya disediakan di sekolah.

LKS merupakan salah satu jenis alat bantu pembelajaran. Tetapi pada kenyataannya LKS yang telah dimiliki oleh siswa selama ini belum memfasilitasi siswa untuk mengkonstruksi sendiri pengetahuannya (Majid, 2013). Isi LKS lebih banyak di tekankan pada penjelasan rinci (definisi) dari sebuah konsep, kemudian diikuti dengan contoh soal dan sejumlah soal-soal latihan. Selain itu, LKS biasa selama ini masih menyajikan materi yang begitu banyak sehingga tidak mendorong siswa untuk tertarik mempelajarinya. Ditinjau dari segi penyajiannya kurang menarik sebab gambar pada LKS tidak berwarna. Sebaiknya LKS yang disajikan harus bisa menarik siswa untuk mempelajarinya, karena LKS itu sendiri merupakan stimulus atau bimbingan guru dalam pembelajaran yang akan disajikan secara tertulis sehingga dalam penulisannya perlu memperhatikan kriteria media grafis sebagai media visual untuk menarik perhatian peserta didik.

Berdasarkan hasil observasi berupa angket analisis kebutuhan yang dilakukan di SMPN 1 Kota Jambi Kelas VII sebanyak 26 siswa, penulis memperoleh sebanyak $85 \%$ siswa menyatakan bahwa materi suhu dan kalor masih sulit dipahami oleh siswa. Hal ini dikarenakan guru sangat jarang menggunakan bahan ajar pendukung seperti LKS dan hanya terfokus satu buku yaitu buku siswa dari permendikbud. Selain itu, ketika mengajar guru hanya menggunakan metode ceramah, dan diskusi-presentasi. Metode ini sebenarnya kurang menunjang untuk materi suhu dan kalor karena pada materi ini terdapat praktikum yang harus membutuhkan bahan ajar lain.

Salah satu metode pembelajaran yang mampu memfasilitasi siswa dalam kegiatan proses pembelajaran di kelas adalah model pembelajaran POE (Predict Observe Explain). Model pembelajaran POE dapat mencakup cara-cara yang dapat ditempuh oleh seorang guru untuk membantu siswa dalam meningkatkan pemahaman konsep pada materi tersebut.
Berdasarkan penelitian yang dilakukan oleh (Kurt dan Ayas 2012) seperti yang dikutip oleh (Rahayu \& Widodo, 2013), model POE yang digunakan dapat meningkatkan pemahaman siswa, karena siswa dapat menggunakan pengetahuan yang telah siswa lakukan dalam menjelaskan suatu konsep fisika. LKS berbasis POE ini akan melatih siswa untuk menggunakan tiga langkah utama dari metode ilmiah yaitu (1) prediction, atau membuat prediksi, membuat dugaan terhadap suatu peristiwa fisika; (2) observation, yaitu melakukan penelitian, pengamatan apa yang terjadi; (3) explanation, yaitu memberikan penjelasan. LKS berbasis POE dengan materi Suhu dan Kalor, diharapkan dapat digunakan sebagai salah satu solusi bahan ajar yang lebih baik pada saat kegiatan proses pembelajaran di kelas.

Beberapa penelitian telah dilakukan terkait dengan pengembangan LKS berbasis POE. Penelitian yang telah dilakukan oleh Siti Rahayu (2013) menunjukkan bahwa LKS tersebut layak digunakan untuk mendukung pembelajaran siswa SMP kelas VII dengan presentase nilai keefektifan sebesar 87,5\% dengan kategori sangat baik. Kekurangan dari LKS yang telah dikembangkan oleh Rahayu yaitu masih belum mengikuti langkah-langkah POE secara keseluruhan hanya menggunakan empat dari enam tahapan POE. Selanjutnya, pada penelitian Rohati (2014) menunjukkan nilai persepsi rata-rata $82,36 \%$ sehingga bahan ajar yang dihasilkan baik dan layak digunakan dalam proses pembelajaran fisika. Kekurangan dari LKS yang dikembangkan oleh Rohati yaitu tampilan penyajian yang masih sangat sederhana. Oleh karena itu peneliti tertarik untuk mengembangkan LKS ini dengan tujuan untuk menyempurnakan penyajian dan tampilan yang lebih baik lagi agar menarik untuk digunakan oleh siswa.

Penelitian ini bertujuan untuk menghasilkan Lembar Kerja Siswa (LKS) berbasis POE (Predict-Observe-Explain) pada materi suhu dan kalor dan dapat mengetahui persepsi siswa terhadap LKS berbasis POE pada materi suhu dan kalor yang dikembangkan. Adapun manfaat dari penelitian ini yaitu menghasilkan LKS berbasis yang dapat digunakan sebagai salah satu media pembelajaran pada materi suhu dan kalor. 


\section{Metode Penelitian}

Model Pengembangan

Jenis penelitian ini adalah penelitian dan pengembangan (research and development). Adapun model pengembangan dalam penelitian ini menggunakan model R\&D Sugiyono yang terdiri dari tahap identifikasi masalah, pengumpulan informasi, desain produk, validasi desain, perbaikan desain, uji coba produk, revisi produk, uji coba pemakaian, revisi produk tahap akhir dan produksi masal (Sugiyono 2007).

Prosedur Pengembangan

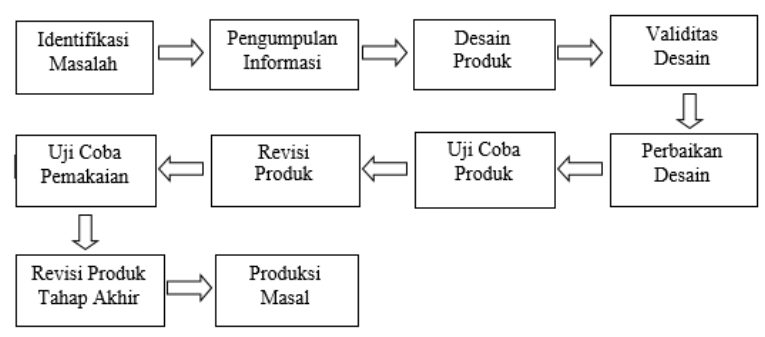

Gambar 1. Konsep Pengembangan Sugiyono

\begin{abstract}
Langkah-langkah pengembangan Sugiyono adalah identifikasi masalah, pengumpulan informasi, desain produk, validasi desain, perbaikan desain, uji coba produk, revisi produk, uji coba pemakaian, revisi produk tahap akhir dan produksi masal. Tetapi, tahapan pengembangan dalam penelitian ini dibatasi hingga tahap revisi produk.
\end{abstract}

\section{1) Identifikasi masalah}

Tahap identifikasi masalah merupakan tahap awal dalam penelitian pengembangan ini, dimana pada tahap ini terjadi proses identifikasi masalah yang ditemukan peneliti terhadap siswa yang akan menjadi subjek peneliti. Tahap identifikasi masalah dilakukan dengan melakukan observasi langsung ke sekolah untuk melihat bagaimana kondisi siswa dan proses pembelajaran siswa di kelas. Selain itu, peneliti juga memberikan lembar observasi awal kepada siswa untuk mengetahui permasalahan apa yang siswa alami dalam proses pembelajaran di kelas.

2) Pengumpulan informasi

Setelah potensi masalah diidentifikasi, selanjutnya dilakukan tahap selanjutnya yaitu tahap pengumpulan informasi. Pengumpulan informasi dilakukan dengan memberikan angket analisis kebutuhan kepada siswa, hal ini dilakukan peneliti untuk mengetahui kebutuhan dari siswa terhadap produk yang akan dikembangkan.

\section{3) Desain Produk}

(Widoyoko, 2014) menyebutkan bahwa "tahap desain dikenal juga dengan istilah membuat rancangan (blueprint). Ibarat bangunan, maka sebelum dibangun gambar rancang bangun (blueprint) di atas kertas harus ada terlebih dahulu". Dalam merancang pembelajaran dilakukan kegiatan berikut:

a. Pemilihan materi yang sesuai dengan silabus SMP/MTs kelas VII serta pembuatan storyboard

b. Pemilihan strategi pembelajaran yang akan diterapkan pada produk

c. Pengumpulan sumber atau referensi yang dibutuhkan untuk pengembangan materi dalam produk yang dikembangkan

Rancangan awal LKS yang akan dikembangkan disajikan dalam bentuk storyboard. Storyboard LKS pada materi suhu dan kalor dapat dilihat pada tabel berikut:

Tabel 1. Story board LKS






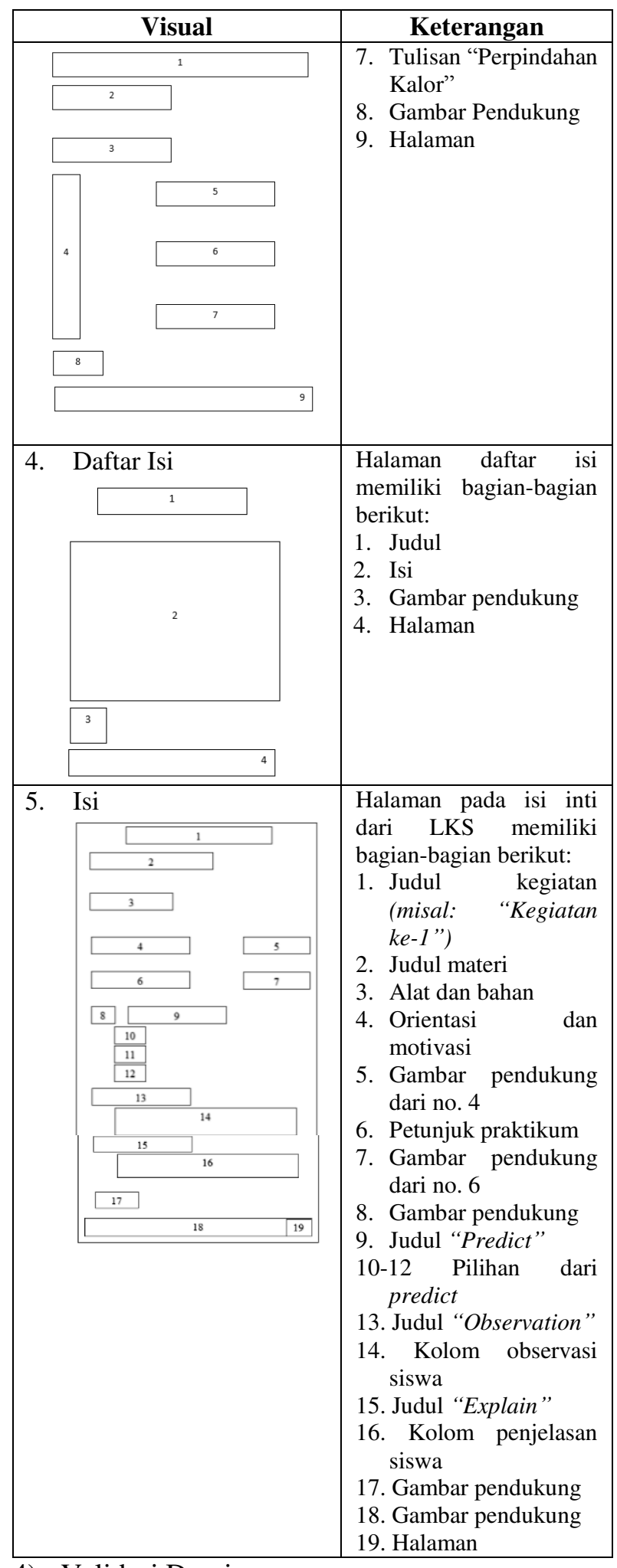

4) Validasi Desain

LKS yang telah dikembangkan kemudian divalidasi oleh ahli desain media dan ahli materi. Pada tahap validitas desain peneliti menggunakan dua macam validitas yaitu validitas ahli materi dan ahli media. Validitas ini dilakukan bertujuan untuk menghasilkan LKS yang layak untuk di uji coba, maka LKS harus melewati tahapan validasi. Validasi materi dan validasi media ini sangat penting demi perbaikan dan peningkatan kualitas LKS yang dikembangkan. Instrumen yang digunakan dalam penelitian ini adalah lembar penilaian berupa angket. Tujuan dari penggunaan angket ini adalah untuk mengetahui kevalidan materi LKS pembelajaran oleh ahli materi dan kevalidan desain LKS pembelajaran oleh ahli desain.

\section{5) Perbaikan Desain}

Setelah desain produk divalidasi oleh validator (materi dan media), peneliti melakukan revisi terhadap desain produk yang dibuat berdasarkan hasil dari penilaian serta masukan atau saran dari validator. Pada penelitian pengembangan yang dilakukan, jenis data yang diambil yaitu data kuantitatif dan kualitatif. Data kualitatif adalah hasil review berupa saran dan pernyataan kesesuaian LKS yang dikembangkan yang diperoleh dari tim validasi yaitu tim ahli materi dan tim ahli desain yang selanjutnya akan digunakan sebagai acuan dalam perbaikan desain. Sedangkan data kuantitatif meliputi skor hasil penilaian dari validator pada angket validasi LKS.

\section{6) Uji Coba Produk}

Uji coba produk merupakan tahap yang dilakukan peneliti setelah merevisi produk desain yang telah dibuat berdasarkan hasil penilaian dari validator. Uji coba produk ini dilakukan kepada siswa SMPN 1 Kota Jambi kelas VII sebanyak 20 orang. Instrumen yang adalah lembar penilaian berupa angket. Tujuan dari penggunaan angket ini adalah untuk mengetahui persepsi siswa terhadap produk LKS yang telah dikembangkan oleh peneliti.

\section{Instrumen Pengumpulan Data}

Penelitian ini memerlukan beberapa data yaitu:

1. Data kualitatif

Data kualitatif yang digunakan dalam penelitian ini adalah proses pembuatan produk serta isi angket yang berupa saran dan perbaikan pengembangan LKS berbasis POE dari validator. Maka instrumen yang digunakan adalah angket validasi. Adapun jenis angket yang digunakan merupakan angket tertutup.

\section{Data kuantitatif}

Data kuantitatif pada penelitian ini adalah data persepsi siswa, maka instrumen yang digunakan adalah angket persepsi siswa dengan Skala Likert berskala genap. Angket yang digunakan untuk mengetahui persepsi siswa adalah angket tertutup dimana pertanyaan yang 
disajikan sedemikian rupa sehingga responden diminta untuk memilih salah satu jawaban yang sesuai dengan karakteristik dirinya.

\section{Analisis Instrumen Penelitian}

1. Analisis Validitas

Dalam penelitian ini, jenis validitas yang digunakan yaitu validitas logis. Dikatakan validitas logis karena validitas ini diperoleh dengan suatu usaha hati-hati melalui cara-cara yang benar sehingga menurut logika akan dicapai suatu tingkat validitas yang dikehendaki.

2. Analisis Reliabilitas

Pengujian reliabilitas instrumen yang dilakukan peneliti yaitu secara internal consistency yaitu dengan mencobakan instrumen sekali saja. Pengujian reliabilitas instrumen yang dilakukan peneliti yaitu dengan menggunakan metode Alpha (Riduwan, 2013).

$$
r_{11}=\left[\frac{n}{n-1}\right]\left[1-\frac{\left(\sum S i_{\text {total }}^{2}\right)}{S i_{\text {total }}}\right]
$$

dengan:

$r_{11}=$ nilai reliabilitas

$\sum S i=$ jumlah varian skor tiap-tiap item

$S t=$ varian total

$n=$ jumlah item

Rumus untuk varians adalah sebagai berikut:

$$
S i=\frac{\sum X^{2}-\frac{\left(\sum X\right)^{2}}{\sum N}}{\sum N}
$$

dengan:

$\mathrm{X}=$ skor-skor pada butir ke-i

$\mathrm{N} \quad=$ jumlah responden

$\Sigma X^{2}=$ jumlah hasil kuadrat skor pada butir ke-i

$\Sigma X \quad=$ jumlah seluruh skor pada butir ke-i

Tabel 2. Interpretasi Nilai $r$

\begin{tabular}{cc}
\hline \multicolumn{1}{c}{ Besarnya nilai $\mathrm{r}$} & Interpretasi \\
\hline $0,800<\mathrm{r} \leq 1,000$ & SangatTinggi \\
$0,600<\mathrm{r} \leq 0,799$ & Tinggi \\
$0,400<\mathrm{r} \leq 0,599$ & Cukup Tinggi \\
$0,200<\mathrm{r} \leq 0,399$ & Rendah \\
$0,000<\mathrm{r} \leq 0,199$ & Sangat rendah \\
\hline
\end{tabular}

Sumber: Riduwan, 2013

Teknik Analisis Data

1. Analisis data kualitatif

Data kualitatif yang berupa saran dari dosen pembimbing disajikan secara deskriptif kualitatif. Sedangkan pada saat melakukan penelitian dilakukan dengan cara dokumentasi (berupa foto)

\section{Analisis data kuantitatif}

Data kuantitatif diperoleh angket validasi ahli serta angket persepsi siswa. Adapun instrumen angket persepsi siswa menggunakan Skala likert bentuk checklist. Analisis data kuantitatif dilakukan secara statistik deskriptif. Adapun skala yang digunakan pada angket persepsi ini yaitu angket dengan skala empat. Adapun langkah-langkah untuk memperoleh hasil kualitatif yaitu sebagai berikut:

a) Mengkuantitatifkan hasil checking dengan memberi skor sesuai dengan bobot yang telah ditentukan sebelumnya, yaitu:

Sangat Setuju (SS) diberi skor 4

Setuju (S) diberi skor 3

Tidak Setuju (TS) diberi skor 2

Sangat Tidak Setuju diberi skor 1

Data persepsi siswa kemudian dianalisis dengan menentukan tabel klasifikasi untuk menentukan kategori skor yaitu dengan cara: mencari skor tertinggi, skor terendah, jumlah kelas, dan jarak interval. Adapun skala yang digunakan pada angket persepsi ini yaitu angket dengan skala empat. Hasil skor responden dinyatakan dengan:

$$
\bar{M}=\frac{\Sigma X}{N}
$$

dengan:

$$
\begin{aligned}
\bar{M} & =\text { Mean } \\
\sum \mathrm{X} & =\text { Jumlah skor } \\
\mathrm{N} & =\text { Jumlah responden }
\end{aligned}
$$

b) Langkah selanjutnya adalah menentukan kriteria atau kategorininterpretasi skor untuk skala Likert dengan skala empat dirumuskan sebagai berikut:

Tabel 3. Kriteria Interpretasi Skor

\begin{tabular}{cc}
\hline Rentang Skor & Kriteria \\
\hline $\mathrm{Mi}+1,5 \mathrm{SDi} \leq \bar{M} \leq \mathrm{Mi}+3,0 \mathrm{SDi}$ & $\begin{array}{c}\text { Sangat } \\
\text { baik }\end{array}$ \\
$\mathrm{Mi}+0 \mathrm{SDi} \leq \bar{M}<\mathrm{Mi}+1,5 \mathrm{SDi}$ & Baik \\
$\mathrm{Mi}-1,5 \mathrm{SDi} \leq \bar{M}<\mathrm{Mi}+$ 0 SDi & Kurang \\
$\mathrm{Mi}-$ 3 SDi $\leq \bar{M}<\mathrm{Mi}-1,5 \mathrm{SDi}$ & $\begin{array}{c}\text { Sangat } \\
\text { kurang }\end{array}$ \\
\hline \multicolumn{2}{c}{ Sumber: Juknis Penilaian Afektif, 2010 }
\end{tabular}

Keterangan :

$\mathrm{Xi}=\frac{1}{2}$ (skor tertinggi + skor terendah $)$ 
$\mathrm{SDi}=\frac{1}{6}($ skor tertinggi - skor terendah $)$

Tabel di atas diturunkan dari kurva normal terhadap skala Likert

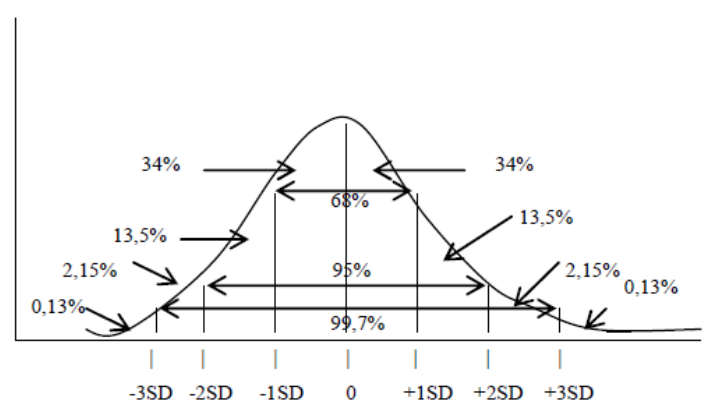

Gambar 2. Kurva Normal

Sumber: Juknis Penilaian Afektif, 2010

dengan:

$\mathrm{Mi} \quad=1 / 2($ Skor Maks - Skor Min $)$

$\mathrm{SDi}=1 / 6($ Skor Maks - Skor Min $)$

\section{7) Revisi Produk}

Revisi produk dilakukan apabila pada saat uji coba produk ditemukan kelemahan atau kekurangan dari LKS yang telah dikembangkan. Kelemahan tersebut akan diperbaiki baik dari segi desain maupun dari segi materi LKS. Revisi juga dilakukan berdasarkan saran dan komentar dari persepsi siswa.

\section{Hasil dan Pembahasan}

\section{1) Identifikasi Masalah}

Pada penelitian pengembangan ini, dilakukan tahap identifikasi masalah sebagai tahap awal untuk memulai penelitian. Peneliti melakukan studi lapangan dengan observasi ke sekolah yaitu SMPN 1 Kota Jambi yang menjadi subjek penelitian, dan siswa kelas VII menjadi objek penelitian. Identifikasi masalah dilakukan dengan menyebarkan lembar observasi kepada siswa yang bertujuan untuk mendapatkan permasalahan awal yang dialami oleh siswa tersebut.

Hasilnya diperoleh bahwa siswa mengalami kesulitan dalam memahami materi Suhu dan Kalor, kesulitan yang ditemukan dari hasil observasi karena bahan ajar yang digunakan terfokus hanya satu buku yaitu buku siswa. Hal ini dikemukakan oleh beberapa siswa di kelas, menurut Menurut Marcello A. Pramudya "Jujur, ketika belajar materi suhu dan kalor, hanya dijelasin dari yang ada di buku. Saat kegiatan yang ada praktikum, sangat jarang dilakukan kegiatan tersebut". Menurut Khaila Nur Hakim
"Bahasa yang dipakai dalam buku sangat tinggi sehingga sulit dipahami, selain itu buku yang digunakan hanya satu buku, mungkin akan lebih baik kalau ada buku tambahan untuk belajar, khususnya untuk kegiatan praktikum". Dari pendapat yang dikemukakan oleh beberapa siswa, dapat disimpulkan bahwa hasil observasi awal ditemukan bahwa siswa kesulitan dalam memahami materi suhu dan kalor dan buku yang digunakan hanya satu buku sehingga siswa mengalami kesulitan belajar.

\section{2) Pengumpulan Informasi}

Tahap selanjutnya yaitu pengumpulan informasi dengan menggunakan angket analisis kebutuhan yang diberikan kepada siswa di kelas. Dari hasil penyebaran angket kebutuhan siswa diperoleh bahwa hanya $73 \%$ mahasiswa yang menyukai materi suhu dan kalor, sisanya $27 \%$ tidak menyukai materi suhu dan kalor. Dari informasi di atas dapat disimpulkan bahwa siswa mengalami banyak kendala ataupun permasalahan dalam mengikuti pelajaran di kelas. Hasil lembar observasi dan angket kebutuhan mahasiswa sangat selaras bahwa masih banyaknya permasalahan yang terjadi dalam pembelajaran IPA khususnya materi suhu dan kalor.

\section{3) Desain Produk}

Tahapan selanjutnya yaitu melakukan desain produk, hal ini bertujuan untuk menghasilkan rancangan produk yang akan dikembangkan. Pada tahap ini, peneliti mulai merancang LKS berbasis POE pada materi suhu dan kalor. Tahap perancangan ini meliputi beberapa aspek, yaitu:

a) Pemilihan materi sesuai silabus SMP/MTs kelas VII kurikulum 2013.

b) Pemilihan model pembelajaran yaitu dengan berdasarkan langkah-langkah POE (Predict-Observe-Explain).

c) Sumber atau referensi yang dibutuhkan terkait materi suhu dan kalor

4) Validitas Desain

Pada tahap validitas desain peneliti menggunakan dua macam validitas yaitu validitas ahli materi dan ahli media. Validitas ini dilakukan bertujuan untuk menghasilkan LKS yang layak untuk di uji cobakan, maka LKS harus melewati tahapan validasi. Validasi materi dan validasi media ini sangatlah penting demi perbaikan dan peningkatan kualitas LKS yang dikembangkan. Dari validator-validator ini diperoleh saran yang berguna untuk perbaikan LKS berbasis POE ini. 
a) Validasi Materi

Pada validasi materi tahap I, validator I menyarankan:

1. Memperbaiki gambar sesuai dengan materi di setiap petunjuk kegiatan.

2. Memperbaiki materi sesuai dengan konsep fisika.

Pada validasi materi tahap I, validator I menyarankan:

1. Memperbaiki langkah-langkah POE

2. Memperbaiki materi sesuai dengan siswa tingkat SMP kelas VII.

Pada validasi ke II, para validator ahli materi diperoleh hasil rata-rata skor 4,16 dengan kategori "baik" tanpa revisi.

\section{b) Validasi Media}

Pada validasi media tahap I, validator I menyarankan:

1. Memperbaiki tampilan cover sampul LKS

2. Memperbaiki bahasa yang digunakan dalam LKS

3. Memperbaiki gambar pada LKS di setiap kegiatan percobaan

Pada validasi media tahap I, validator juga menyarankan:

1. Memperbaiki tampilan cover sesuai dengan tema materi LKS.

2. Memperbaiki tulisan dan font pada LKS.

Pada validasi media tahap II, para validator diperoleh skor rata-rata 3,8 dengan kategori baik. Berrdasarkan hasil validasi materi dan media ini peneliti menyimpulkan bahwa dari segi materi dan media produk LKS berbasis POE (Predict-Observe-Explain) pada materi suhu dan kalor telah layak untuk di uji coba.

\section{5) Perbaikan Desain}

Dari tahap validasi desain tentu terdapat perbaikan desain yang diperoleh dari hasil validasi materi dan validasi media. Adapun perbaikan desain berdasarkan hasil validasi materi dan validasi media adalah sebagai berikut:

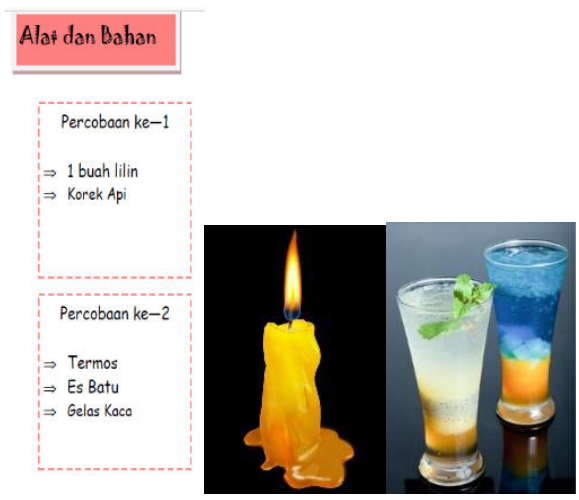

Gambar 3. Gambar LKS sebelum diperbaiki

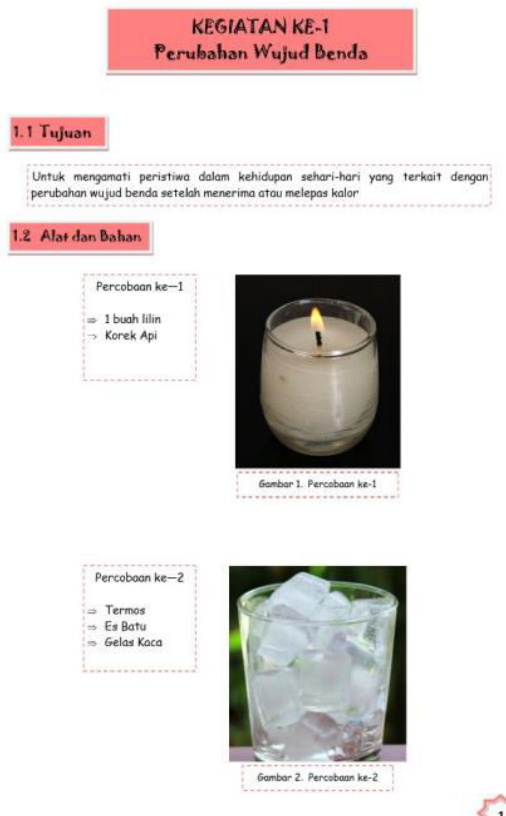

At.

Gambar 4. Gambar LKS setelah diperbaiki

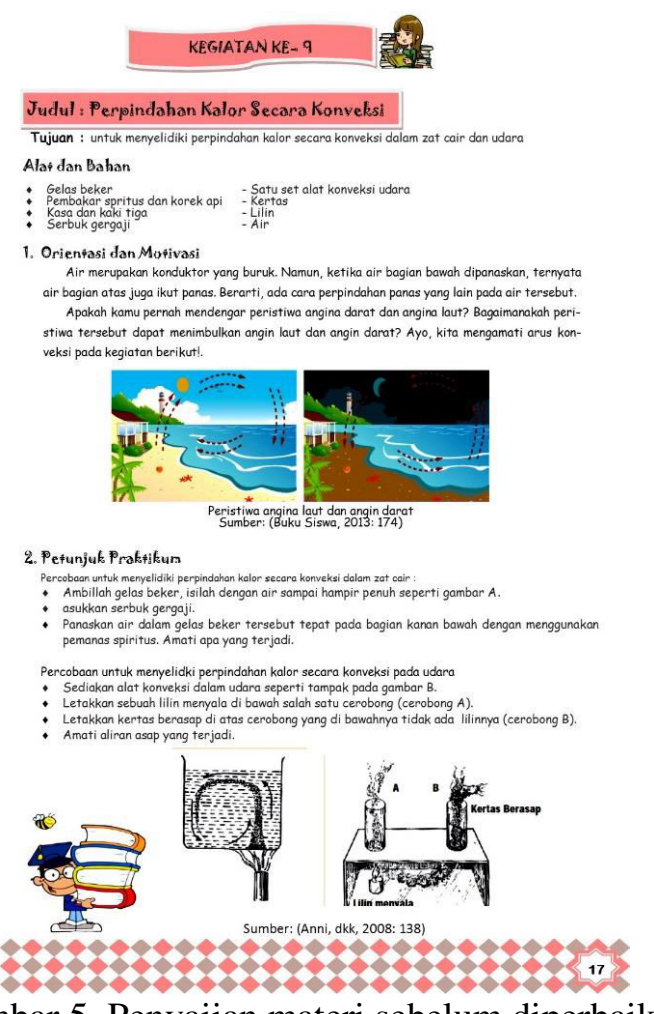

Gambar 5. Penyajian materi sebelum diperbaiki 


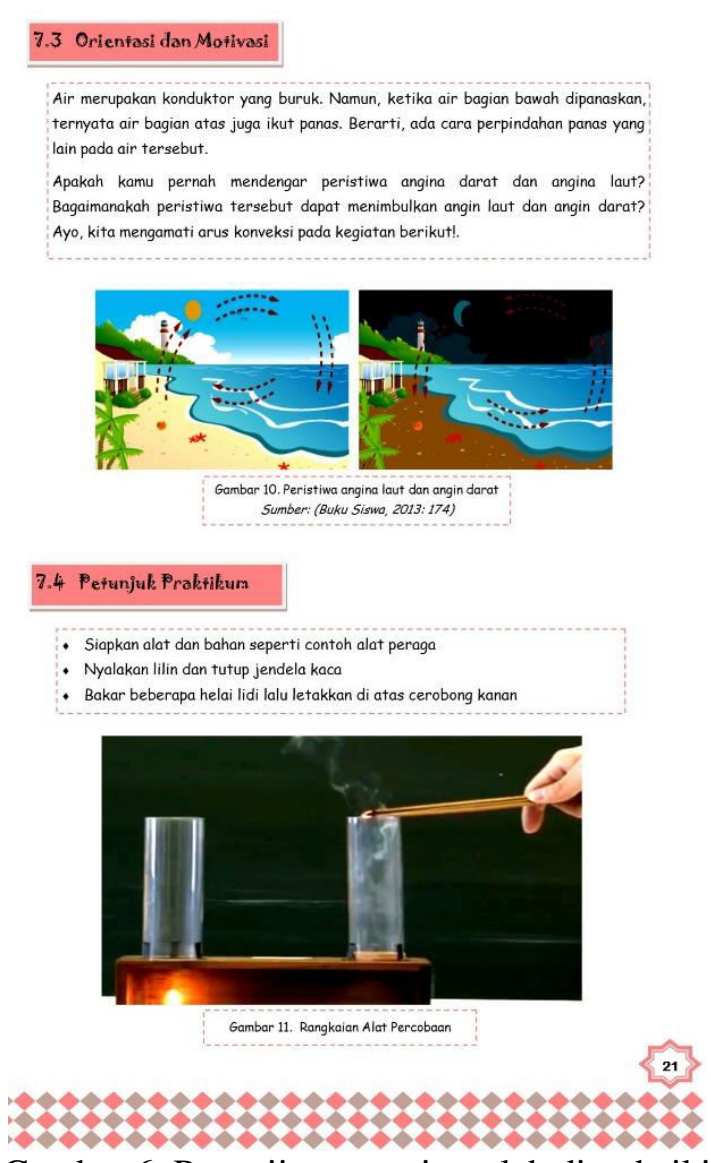

Gambar 6. Penyajian materi setelah diperbaiki

\section{6) Uji Coba Produk}

Tahap selanjutnya setelah dilakukan perbaikan desain yaitu melakukan uji kelayakan LKS ke sekolah. Adapun sekolah yang dipilih sebagai tempat untuk menguji kelayakan LKS yaitu di SMPN 1 Kelas VII C dan VII H sebanyak 26 orang. Hasil uji coba pada kelas VII C digunakan untuk menentukan reliabilitas angket, sedangkan hasil uji coba pada kelas VII $\mathrm{H}$ digunakan untuk menentukan persepsi siswa terhadap LKS berbasis POE yang telah dikembangkan.

Uji reliabilitas dilakukan dengan cara perhitungan koefisien korelasi dari persamaan alfa. Dari perhitungan dengan menggunakan persamaan tersebut diperoleh nilai reliabilitas angket sebesar $r_{11}=0,420$ dengan kategori reliabilitas cukup. Dari perhitungan tersebut, maka dapat disimpulkan bahwa angket dapat dipercaya dan digunakan untuk mengambil data terhadap kelayakan LKS berbasis POE yang telah dikembangkan.

Tahap selanjutnya yaitu melakukan uji coba untuk melihat kelayakan LKS berbasis POE. Uji coba dilakukan di kelas VII H SMPN 1 Kota Jambi, dimana data yang diambil merupakan persepsi siswa terhadap LKS berbasis POE.
Berdasarkan angket persepsi siswa didapatkan skor angket sebagai berikut:

Tabel 4. Hasil Persepsi Siswa

\begin{tabular}{ccc}
\hline Aspek Penilaian & Skor & Keterangan \\
\hline Hasil Produk & 22 & Sangat Baik \\
Keefektifan & 28,35 & Sangat Baik \\
Rata-Rata Aspek & 50,35 & Sangat Baik \\
keseluruhan & & \\
\hline
\end{tabular}

Dari data di atas dapat disimpulkan bahwa LKS berbasis POE yang telah dikembangkan dikategorikan sangat baik dan layak untuk dikembangkan serta dapat digunakan sebagai bahan ajar tambahan khususnya pada materi suhu dan kalor untuk siswa SMP kelas VII.

\section{7) Revisi Produk}

Revisi dilakukan berdasarkan penilaian dan pemikiran pribadi oleh penulis serta berdasarkan saran dan komentar yang telah diberikan oleh dua orang validator yaitu ahli materi dan ahli media serta hasil uji coba persepsi siswa terhadap LKS yang dikembangkan. Adapun revisi yang dilakukan menyangkut tentang konstruk atau tampilan LKS, bahasa atau kalimat yang digunakan pada LKS dan isi materi yang terdapat pada LKS. Berdasarkan dari hasil revisi ini, LKS mengalami banyak perubahan dari awal hingga akhir LKS dari segi materi maupun desain. Berikut adalah hasil revisi yang telah dilakukan oleh peneliti:

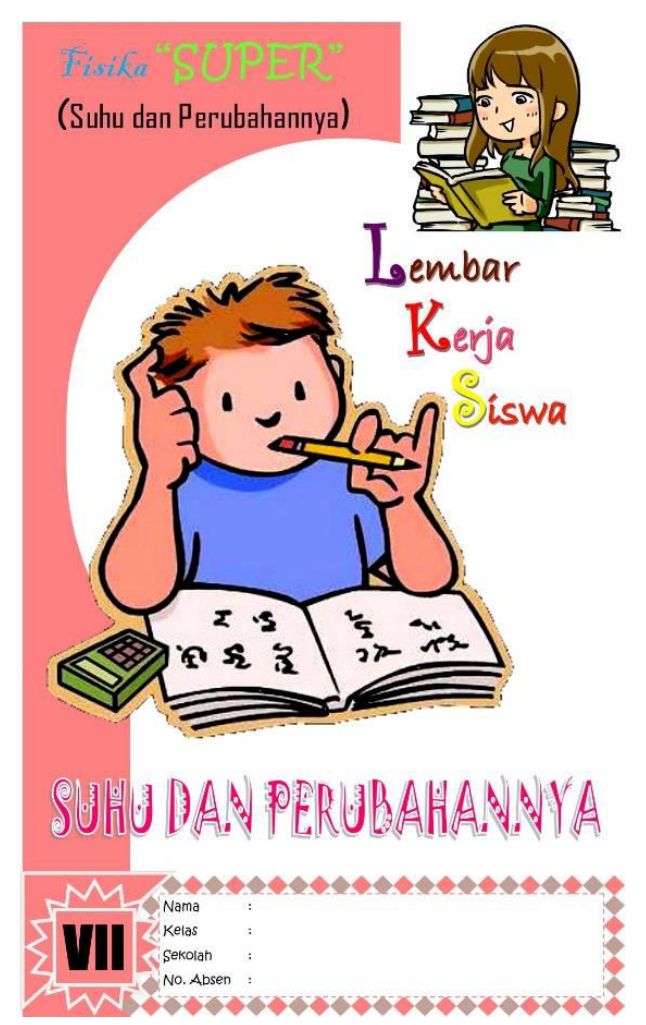


Gambar 6. Tampilan cover LKS sebelum direvisi

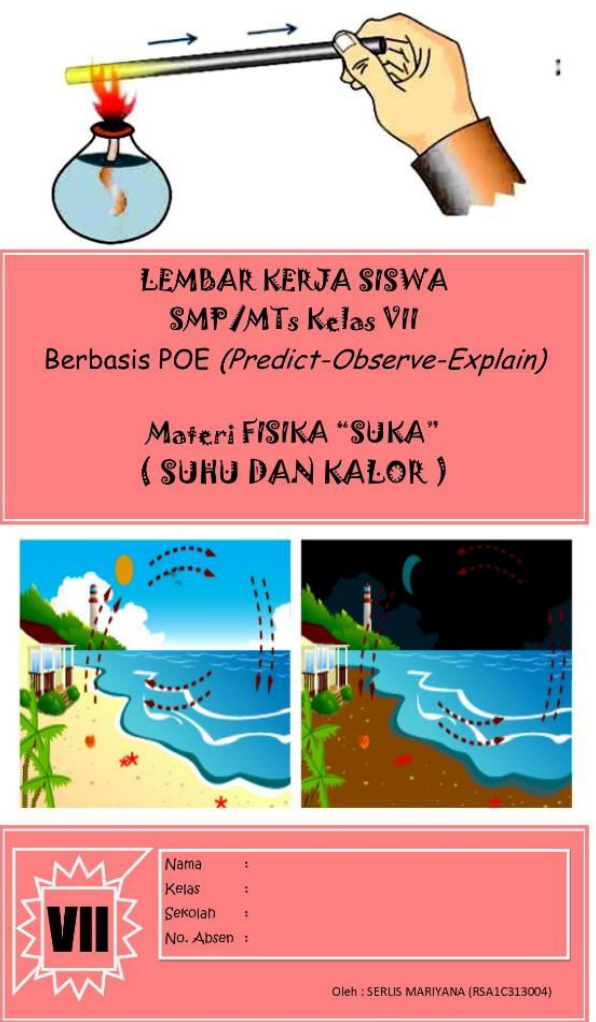

Gambar 7. Tampilan cover LKS setelah direvisi

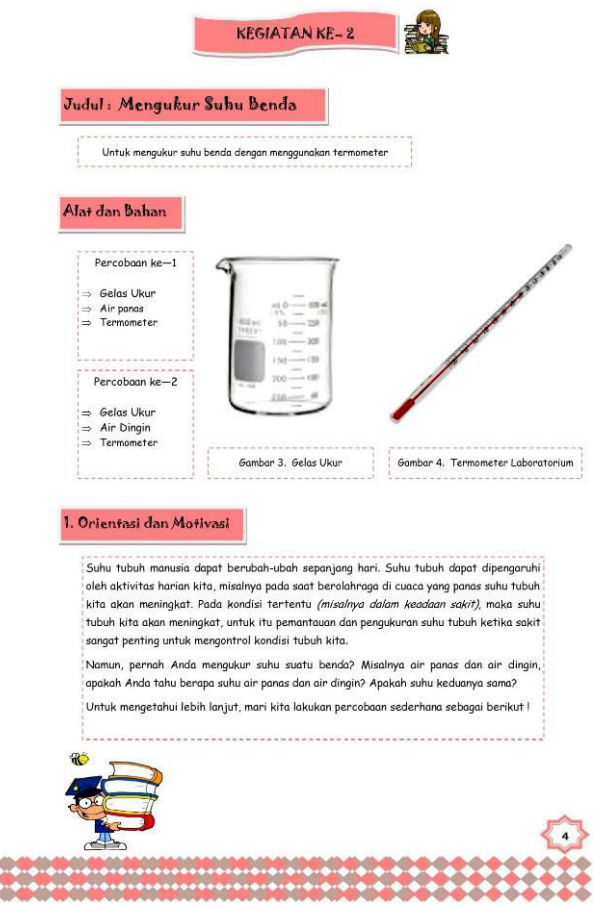

Gambar 8. Tampilan kegiatan percobaan sebelum direvisi

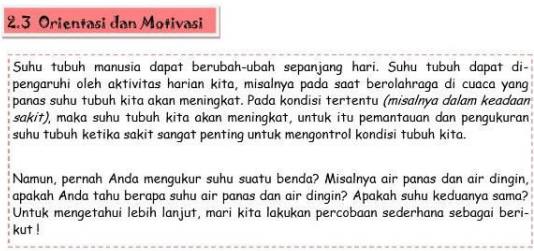

2.4 Pefunjuk Praktikum

$$
\text { Percobaan ke-1 }
$$

- Siapkan alat dan bahan untuk percobaan ke-1

: Masukkan air panas ke dalan gelas ukur

Percobaan ke-2

- Siapkan alat dan bahan untuk percobaan ke-2

- Masukkan air dingin ke dalom gelas uks

- Ukurlah suhu air dingin dengan menggunakan termometer

14. 2.5 PREDIKSI
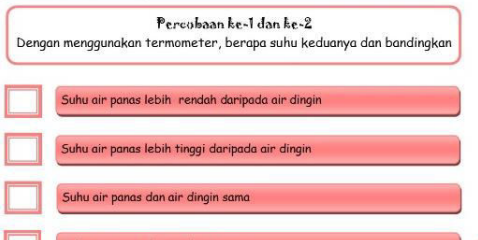

Sulu air panas dan air dingin sama

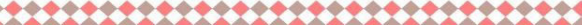

Gambar 9. Tampilan kegiatan percobaan setelah direvisi

Kajian Produk Akhir

a) Spesifikasi Produk

Adapun spesifikasi LKS yang telah selesai dikembangkan yaitu LKS berbasis POE berupa media cetak dengan berukuran $21.1 \times 29.8$ $\mathrm{cm}$ dan dibuat dengan full colour yang didesain semenarik mungkin, kegiatan pembelajaran pada LKS ini terdiri 9 kegiatan yaitu perubahan wujud benda, mengukur suhu benda, pemuaian benda padat, pemuaian benda cair, pemuaian benda gas, perpindahan kalor secara konduksi, konveksi, radiasi dan kestabilan tubuh makhluk hidup. LKS ini juga disusun berdasarkan langkah-langkah dari model pembelajaran POE yang lengkap dari LKS sebelumnya yaitu terdiri dari orientation and motivation (orientasi dan motivasi), introduction the experiment (petunjuk praktikum), prediction (prediksi), observation (observasi) and explanation (penjelasan) sedangkan LKS sebelumnya tidak ada tahapan orientasi dan motivasi yang diperlukan untuk proses awal pada kegiatan pembelajaran. Kemudian produk yang telah diselesaikan oleh peneliti berupa LKS berbasis POE memiliki tampilan yang terdiri atas cover, kata pengantar, pendahuluan, peta konsep, daftar isi, halaman kegiatan percobaan dan daftar pustaka. Berikut tampilan LKS yang telah selesai dikembangkan. 


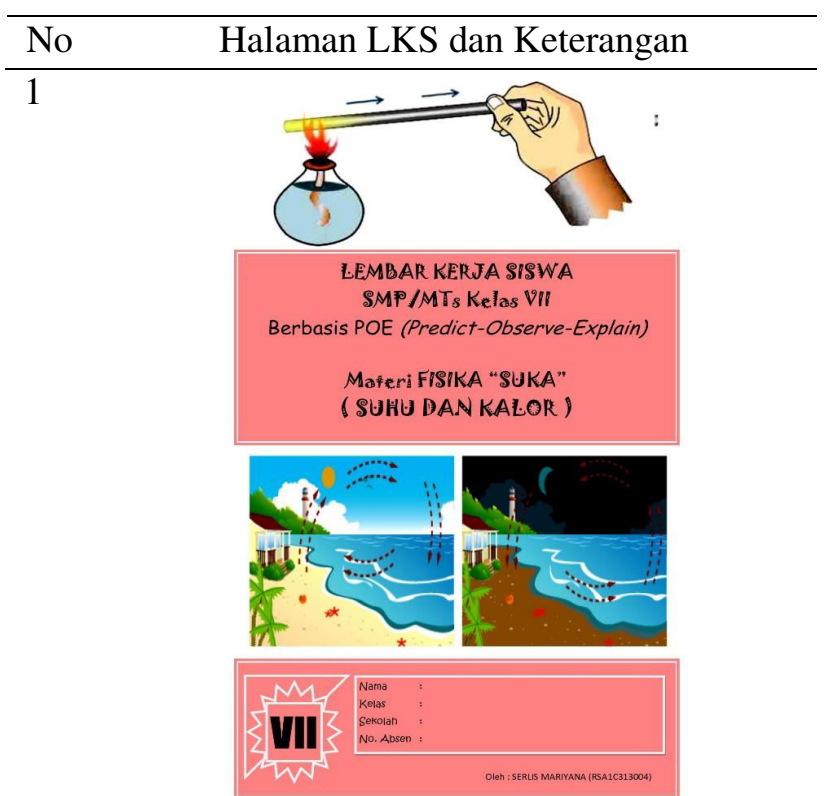

Halaman ini adalah cover dari LKS yang berisi Judul Materi, tingkat pengguna, dan bagian identitas pengguna. Layout untuk cover berwarna pink dan menggunakan gambar yang berkaitan dengan materi yang dipelajari.

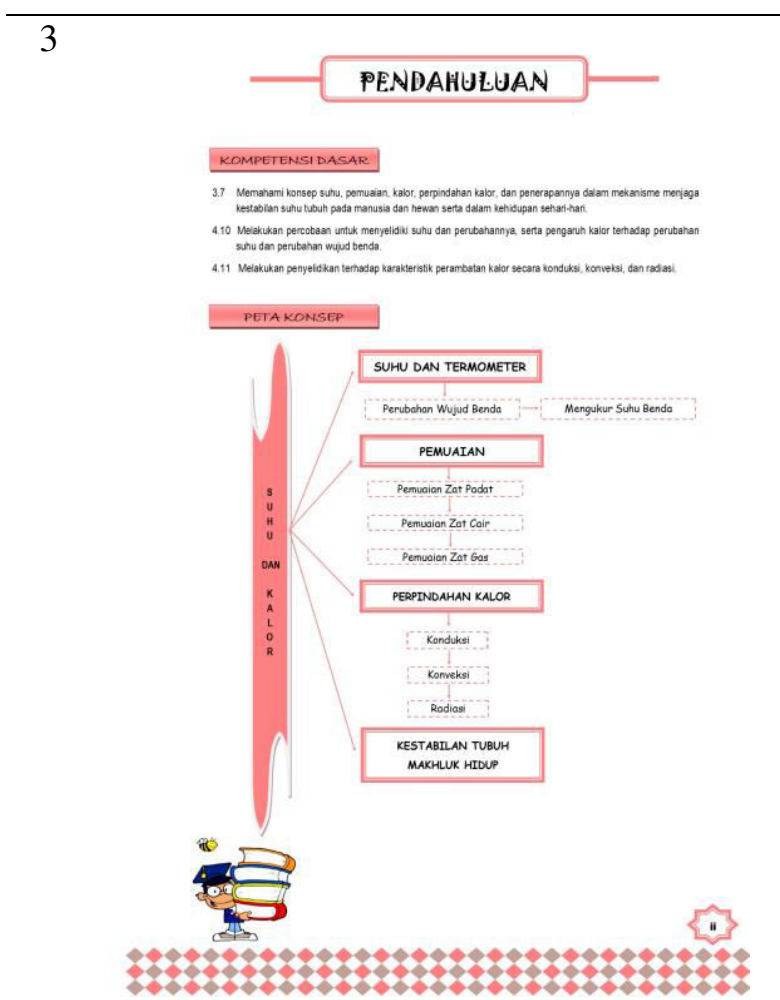

Halaman ini terdapat pendahuluan yang terdiri dari kompetensi dasar dan peta konsep LKS.

\section{4}
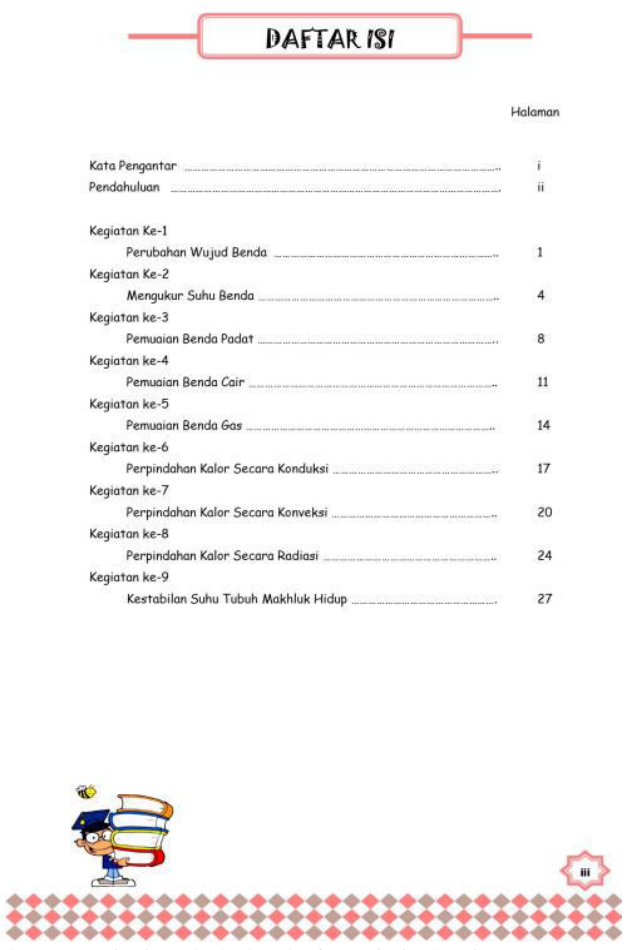

Halaman ini adalah daftar isi dari LKS yang berisi keterangan halaman dari isi LKS seperti halaman sub bab materi. 


\section{5}

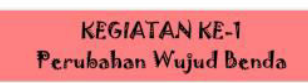

\subsection{Tujuan}

Untuk mengamati peristiwa dalam kehidupan sehari-hari yang terkait dengan perubahan wujud benda setelah menerima atau melepas kalor

1.2 Alat dan Bahan
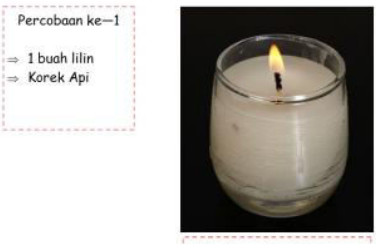

Genbar 1. Percoboon ke-1

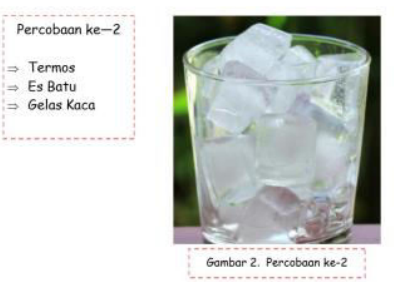

te te te te te te te

Halaman ini adalah kegiatan LKS 1 yang berisi judul kegiatan, tujuan kegiatan serta alat dan bahan kegiatan.
1. 3 Orientasi dan Motivasi

Apakah kanu pernah menyolakan lilin? Tentu kita pernah menyalakan lilin, misolnyo ketika kita ulang tahun, tentu kita akan menyolakan Tilin di atas kue ulang tahun. thau di saat sedang mati i istrik pada malam hari kita membutuhkan cahoya, dan kito

Lalu, di saat kita merasa haus ketika cuoca terik, tentu akan terasa nikmat apabila: kita meminum sesuatu yang dingin. Salah satu hal yang sederhana yang kita lakukan Yann mengambil es balu di kulkas lalu di letakkan ke dalam gelas kaca. Namun, se.

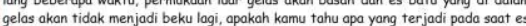
batu yang beku berubah menjidi

\subsection{Petunjuk Prabtikum}

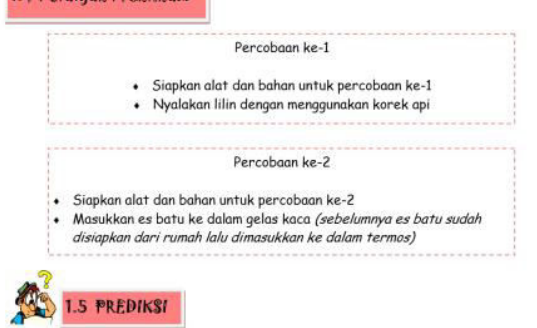

\section{Percolbaan ke-1}

- Setelah lilin menyala, amati apa yang terjadi pada lilin tersebut I

Lilin akan mencair

Lilin aken terbaker

Lilin tidak akan mencair

Jawoban 1 dan 2 benar

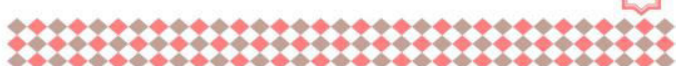

Halaman ini berisi permulaan dari tahapan atau langkah-langkah dari POE (PredictObserve-Explain) yaitu orientasi dan motivasi, petunjuk praktikum dan prediksi dari siswa.

7

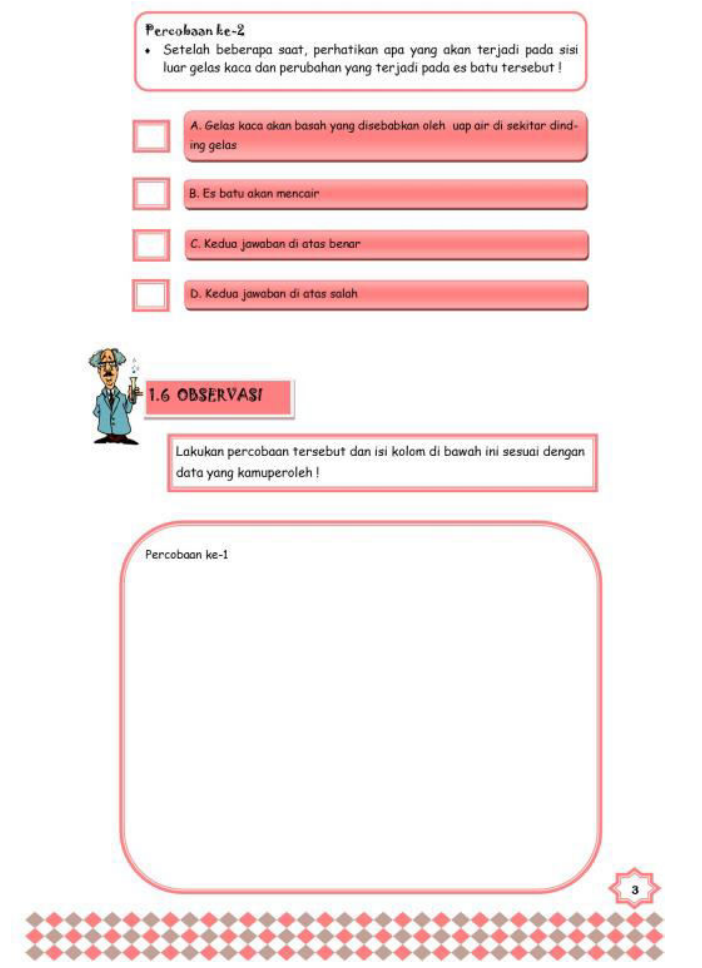

Halaman ini berisi lanjutan dari tahapan atau langkah-langkah dari POE (PredictObserve-Explain) yaitu isi dari prediksi percobaan untuk siswa dan kolom observasi yang akan digunakan untuk hasil observasi yang telah dilakukan oleh siswa. 
8

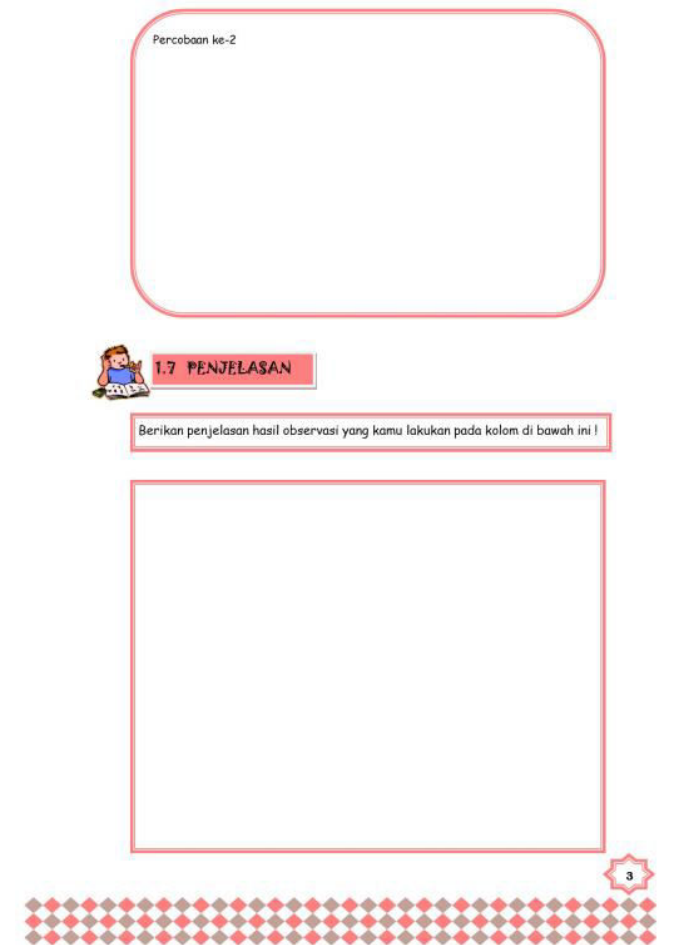

Halaman ini berisi lanjutan dari tahapan atau langkah-langkah dari POE (PredictObserve-Explain) yaitu penjelasan dari hasil observasi siswa.

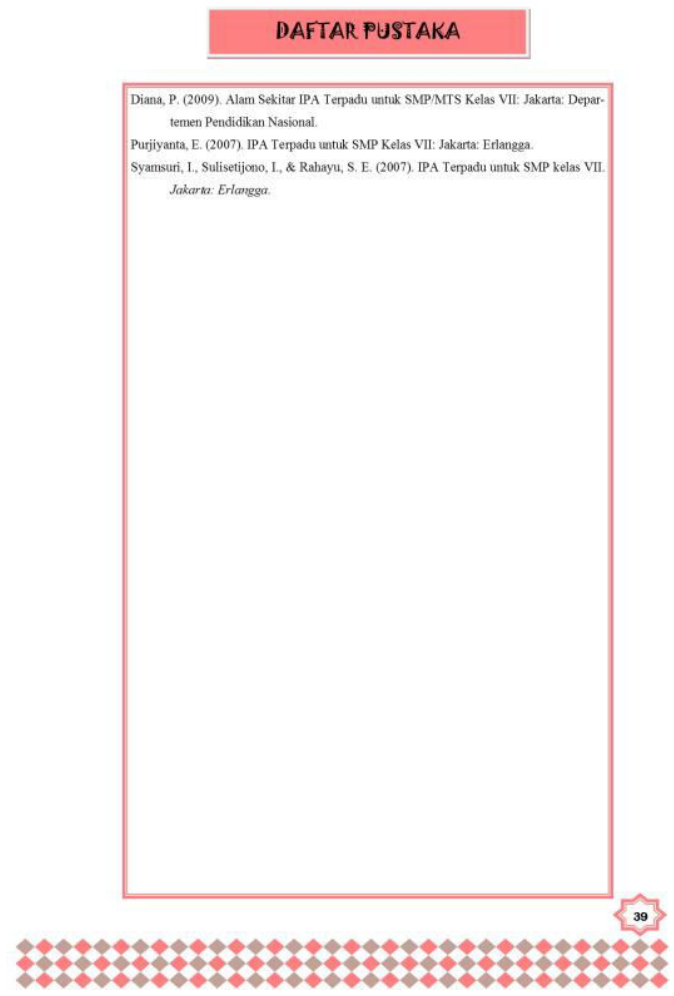

Halaman ini berisi daftar pustaka LKS

b) Keunggulan Produk
Keunggulan dari LKS ini yaitu dilengkapi gambar dan petunjuk praktikum yang sederhana serta terdapat uraian tahapan kegiatan yang disajikan secara jelas dan terperinci sesuai dengan tahapan POE.. Selain itu menurut (Kurt dan Ayas 2012) LKS berbasis POE ini dapat meningkatkan motivasi dan pemahaman siswa berdasarkan kegiatan percobaan yang telah dilakukan siswa.

\section{c) Kelemahan Produk}

Kekurangan dari LKS ini yaitu belum memiliki contoh soal dan pengayaan setelah melakukan percobaan di setiap kegiatan.

\section{Simpulan dan Saran}

Simpulan

Lembar Kerja Siswa (LKS) Berbasis POE pada materi Suhu dan Kalor ini telah melalui proses validasi, baik validasi materi maupun validasi media. Proses validasi ini berlangsung dengan beberapa kali validasi disertai dengan adanya revisi untuk memperbaiki LKS sesuai dengan penilaian dan komentar yang diperoleh dari validator. Validasi materi berlangsung sebanyak dua kali yang dilakukan untuk memperoleh kelayakan LKS dari aspek materi. Dari validasi ini, diperoleh hasil bahwa validasi tahap pertama diperoleh rata-rata skor penilaian sebesar 3.4 dengan kategori "baik". Namun, masih ada yang perlu diperbaiki sehingga materi harus kembali di validasi. Validasi tahap kedua diperoleh rata-rata skor penilaian sebesar 41.6 dengan kategori "baik".

Validasi media berlangsung sebanyak dua kali yang dilakukan untuk memperoleh kelayakan LKS dari aspek media. Dari validasi ini, diperoleh hasil bahwa validasi tahap pertama diperoleh hasil skor penilaian rata-rata sebesar 3.2 dengan kategori "cukup baik". Validasi tahap kedua diperoleh hasil skor penilaian rata-rata sebesar 3.8 dengan kategori "baik". Hasil analisis terhadap data persepsi siswa diperoleh skor penilaian ratarata sebesar 3.37 dengan kategori "sangat setuju" bahwa LKS berbasis POE (Predict-ObserveExplain) pada materi suhu dan kalor layak untuk dikembangkan.

Saran

Dalam penelitian ini hanya hingga tahap revisi produk, disarankan untuk penelitian selanjutnya dapat melakukan tahapan penelitian dan pengembangan secara keseluruhan hingga tahap produksi masal. LKS ini belum diuji coba mengenai aspek keterbacaan sehingga disarankan untuk dapat melakukan uji coba mengenai aspek 
keterbacaan. LKS ini juga disarankan untuk melengkapi LKS dengan soal pengayaan setelah melakukan percobaan serta dapat dijadikan sebagai bahan pembanding untuk menghasilkan atau mengembangkan bahan ajar yang lebih baik lagi sehingga mampu meningkatkan motivasi belajar siswa yang lebih tinggi lagi.

\section{Daftar Pustaka}

Belawati, T. (2003). Pengembangan bahan ajar. Jakarta: Universitas Terbuka.

Diana, P. (2009). Alam Sekitar IPA Terpadu untuk SMP/MTS Kelas VII: Jakarta: Departemen Pendidikan Nasional.

Haysom, J., \& Bowen, M. (2010). Predict, observe, explain: Activities enhancing scientific understanding: NSTA Press.

Lindgren, H. C. (1969). An introduction to social psychology: Wiley.

Majid, A. (2013). Strategi pembelajaran: Bandung: PT Remaja Rosdakarya.

Prastowo, A. (2014). Pengembangan bahan ajar tematik. Yogyakarta. DIVA Pr.

Purjiyanta, E. (2007). IPA Terpadu untuk SMP Kelas VII: Jakarta: Erlangga.

Rahayu, S., \& Widodo, A. (2013). Pengembangan Perangkat Pembelajaran Model POE Berbantuan Media "I am a Scientist". Innovative Journal of Curriculum and Educational Technology, 2(1).

Riduwan, M. (2013). Belajar Mudah Penelitian Untuk Guru-Karyawan dan Peneliti Pemula. Bandung: Alfabeta.

Sugiyono, D. (2000). Metode Penelitian. Bandung: CV Alvabeta.

Sugiyono, P. Dr. 2012. Metode Penelitian Kuantitatif, Kualitatif dan R\&D. Cetakan Ke-15. Alfabeta: Bandung.

Suparno, P. (2007). Metodologi Pembelajaran Fisika. Yogyakarta: Universitas Sanata Dharma.
Syamsuri, I., Sulisetijono, I., \& Rahayu, S. E. (2007). IPA biologi untuk SMP kelas VII. Jakarta: Erlangga.

Widoyoko, E. P. (2014). Teknik penyusunan instrumen penelitian: Yogyakarta: Pustaka Pelajar.

Winarsih, A., Sulityoso, H., Amd, M. Z., \& Suyanto, S. (2008). Ipa Terpadu: Jakarta: Gramedia Widiasarana Indonesia (Grasindo). 